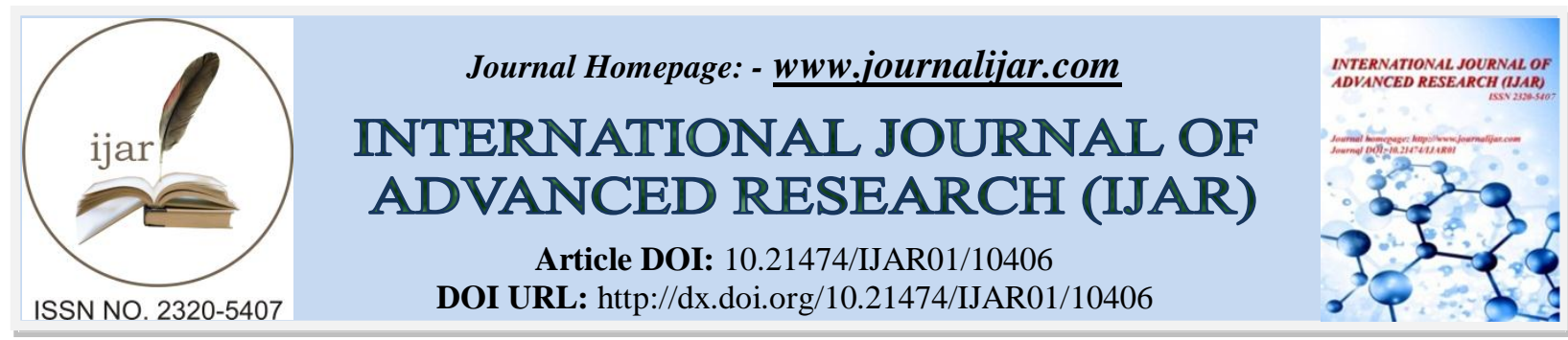

RESEARCH ARTICLE

\title{
APPLICATION OF ADMINISTRATIVE RESPONSIBILITY FOR TRAFFIC OFFENSES
}

\begin{abstract}
Allayarov N
Manuscript Info

Abstract

Manuscript History

Received: 30 November 2019

Final Accepted: 31 December 2019

Published: January 2020

Copy Right, IJAR, 2020,. All rights reserved.

\section{Introduction:-}

Road safety issues are among the most important tasks of the national security of the Republic of Uzbekistan. Traffic accidents and their consequences cause enormous material and moral damage both to society as a whole and to individuals. As the head of state noted, “... in our country, where in total there are more than 2.5 million units of automobile transport, over 1600 people died on the roads during this period. Is this not a tragedy, not a huge loss?»1
\end{abstract}

The situation with traffic accidents, which has reached scale in recent problems, required the development and implementation of a state strategy in the field of road safety.

In Uzbekistan last year, 71 people died in road traffic accidents, 177 received injuries of varying severity.

Problematic issues in the field of road safety have been repeatedly voiced by the head of state during the solemn meetings, which are being actively implemented. As the head of state rightly noted, "... The reason for such offenses is related to problems in the legal culture. Until we form a high legal culture in our society, put an end to this phenomenon, violations of the law will continue".

The Code of the Republic of Uzbekistan on administrative responsibility regulates the procedure for attracting individuals and officials for violations of transport, in the field of road facilities and communications. This code contains a provision stipulating responsibility for driving a vehicle in a state that remains relevant; the issue of holding the driver of a vehicle legally required by a police officer to undergo a medical examination for intoxication remains an issue (Article 131).

In 2018, the administrative courts of the Republic of Uzbekistan examined 57179 cases of offenses related to driving while intoxicated and evading drivers from being examined for intoxication (Article 292). Of these, 44,367 drivers were deprived of their rights, and 6,264 fell under administrative arrest.

When considering administrative offenses of this category, it is customary to consider the subject as the person who committed the wrongful act or omission, and the subjective side as the presence of a certain mental attitude of the person to the committed act.

According to the foreign scientist Kostylev A.K. the current situation in the field of traffic and the country as a whole, the acute situation with the use of alcohol, the study of the forms and methods of work of state bodies and public organizations to normalize it, an attempt was made to outline the main provisions of the comprehensive

Corresponding Author:- Allayarov N 
implementation of the state approach to the problem of offenses in the field of traffic related to the state intoxication of its participants.

Having analyzed this offense, it is necessary to conclude that the same responsibility for driving a vehicle while intoxicated, failure to comply with a legal driver's requirement for an authorized official to undergo a medical examination on a state of intoxication negatively affects the state of road safety. So, as with the driver's refusal to undergo a medical examination, the driver is "not recognized as drunk," he also does not actually spend time on the examination procedure and does not bear any consequences, including limiting certain rights, when drug intoxication is established.

So according to the scientist Ivanova O.A. it concludes that it is necessary to legislate a mechanism for registering drivers in a medical institution if they show signs of psychiatric contraindications for activities related to a source of increased danger; observing them for a certain period, and then resolving the issue of establishing a diagnosis of "alcoholism", "drug addiction" or "substance abuse" with the subsequent termination of the right to drive a vehicle.

It should be noted that the driver, while undergoing training on the right to drive vehicles, carefully studied the rules of the road, passed exams in units of the road safety service and received a driver's license. So, in accordance with paragraph "g" of the Rules of the Road, the driver, at the request of employees of the internal affairs bodies, to undergo an examination for intoxication. If the rules stipulate an obligation, why should the driver be given the opportunity to refuse to undergo a medical examination therefore, the refusal to carry out an examination cannot constitute an administrative offense stipulated by the norm in Article 136 of the Code of the Republic of Uzbekistan on administrative responsibility, despite the fact that the employee of the internal affairs bodies requires the driver to pass surveys are legal.

Thus, the Main Directorate of Road Safety of the Ministry of Internal Affairs of the Republic of Uzbekistan provides for the organization of road safety, including the prevention and suppression of violations of the rules of the road, the prevention of traffic accidents and traffic congestion, the identification and identification of persons involved in the commission of offenses.

It is necessary to pay attention to what we are proposing, that the refusal to be examined for a state of intoxication has legal significance, the recognition of the fact that he is in a state of intoxication. Therefore, that a person who is confident that he has not consumed alcoholic beverages and other substances that cause him to become intoxicated, according to a logical opinion, having passed the examination, he will confirm his innocence.

Summing up the above, it is necessary to supplement article 131 of the Code of the Republic of Uzbekistan on administrative responsibility with part four of the following content:

"A medical examination for the state of intoxication of a person driving a vehicle in order to establish signs of an administrative offense and an objective consideration of the case of an administrative offense is carried out in the manner prescribed by this article. Refusal to undergo a medical examination means recognition by a citizen of the fact of being in a state of intoxication."

Article 136 of the Code of the Republic of Uzbekistan on administrative responsibility evasion of drivers of vehicles and other road users from passing the examination for intoxication must be supplemented in article 135 of this code or excluded from the code.

In this regard, it should be noted that the driver's refusal of the legal requirement of an authorized official to undergo a medical examination for a state of intoxication must be regarded as a recognition of him in a state of intoxication.

\section{Literature:-}

1. Report of the President of the Republic of Uzbekistan Shavkat Mirziyoyev at the solemn meeting dedicated to the 26th anniversary of the adoption of the Constitution of the Republic of Uzbekistan of December 12, 2018.

2. Kostylev A. K. Administrative liability for offenses in the field of traffic associated with the state of intoxication of its participants. Abstract. Candidate of Law, Tyumen, 1998.

3. Ivanova O.A. Administrative liability of road users for offenses committed while intoxicated. Avtoref.k.ju.s., Omsk., 2004. P.24.

4. Decree of the President of the Republic of Uzbekistan "On measures to further improve the system for ensuring road safety" dated July 11, 2017 No. PP-3127. 